УДК 159.922

DOI https://doi.org/10.26661/2310-4368/2020-3-5

\title{
ВИЯВЛЕННЯ ВЗАЕМОЗВ'ЯЗКІВ МІЖ КОГНІТИВНИМИ ЧИННИКАМИ АДАПТИВНОСТІ БЕЗРОБІТНИХ ПІД ЧАС КОРОТКОСТРОКОВОГО ПРОФЕСІЙНОГО ПЕРЕНАВЧАННЯ
}

\author{
Хубетов О. В. \\ аспірант кафедри психології \\ Інститут підготовки кадрів державної служби занятості Украӥни \\ вул. Нововокзальна, 17, Київ, Украӥна \\ orcid.org/0000-0003-2617-049X \\ 060315@ukr.net
}

\begin{abstract}
Ключові слова: адаптивність, когнітивні чинники

адаптивності, інтелект, критичне мислення, особисті изіності, самостійність, творче мислення.
\end{abstract}

Статтю присвячено дослідженню не досить освітлених у сучасному науковому просторі питань щодо впливу когнітивних чинників на рівень адаптивності безробітних при короткостроковому професійному перенавчанні, виявленню взаємозв'язків між когнітивними чинниками адаптивності та визначенню поміж цих чинників таких, рівні яких можливо змінити в процесі проведення психологічного тренінгу для позитивного впливу на рівень адаптивності. Здійснено огляд сучасних досліджень адаптивності особистості при зміні занять і життєвих ролей та факторів, що впливають на неї в різноманітних обставинах життєдіяльності.

За результатами факторного аналізу, проведеного для чинників, які за попередньо проведеним кореляційним аналізом мають статистично значимі зв'язки 3 адаптивністю безробітних при професійному перенавчанні, виділено п'ять об'єднаних факторів. У сумі ці фактори описують 66,89 \% аналізу вибірки всіх когнітивних чинників, що мають вплив на рівень адаптивності. Цими факторами $\epsilon$ фактор інтелекту i критичного мислення, фактор самостійності та цілеспрямованості, фактор традицій і добропорядності, фактор влади, фактор творчості. Визначено критерії відбору когнітивних чинників адаптивності для комплексної програми по підвищенню адаптивності безробітних при короткостроковому професійному перенавчанні, а саме: наявність найбільших статистично значимих кореляційних зав'язків 3 рівнем адаптивності безробітних при короткостроковому професійному перенавчанні; можливість впливу на їх рівень за досить обмежений термін психологічного тренінгу; корекція рівнів когнітивних властивостей без втрати при цьому особистісної цілісності та можливостей саморозвитку і самовдосконалення; присутність психологічного чинника, що обирається для програми, у складі об'єднаного фактору впливу на адаптивність. Критичне мислення, особисті цінності «самостійність» та «самостійність в діяльності», творче мислення визначено чинниками, які можливо використати у комплексній програмі по підвищенню адаптивності безробітних при короткостроковому професійному перенавчанні. 


\title{
IDENTIFYING THE RELATIONSHIP BETWEEN COGNITIVE FACTORS OF THE ADAPTIVITY OF THE UNEMPLOYED WITH SHORT-TERM PROFESSIONAL TRAINING
}

\author{
Khubetov A. V. \\ Postgraduate Student at the Department of Psychology \\ Ukrainian State Employment Service Training Institute \\ Novovokzalna str., 17, Kyiv, Ukraine \\ orcid.org/0000-0003-2617-049X \\ 060315@ukr.net
}

Key words: adaptability, cognitive factors of adaptability, intelligence, critical thinking, personal values, independence, creative thinking.
The article is devoted to the study of insufficiently covered issues in the modern scientific space on the influence of cognitive factors on the level of adaptability of the unemployed in short-term vocational retraining, identifying relationships between cognitive factors of adaptability and identifying between these factors whose levels can be changed in the process to the level of adaptability. The review of modern researches of adaptability of the person at change of occupations and vital roles and the factors influencing it in various circumstances of vital activity is carried out. According to the results of the factor analysis conducted for the factors that according to the previous correlation analysis have statistically significant relationships with the adaptability of the unemployed in vocational retraining, five combined factors were identified. In total, these factors describe $66.893 \%$ of the sample analysis of all cognitive factors that affect the level of adaptability. These factors are the factor of intelligence and critical thinking, independence and purposefulness, traditions and decency, power, and the factor of creativity. Criteria for selecting cognitive factors of adaptability for a comprehensive program to increase the adaptability of the unemployed in short-term vocational retraining, namely: the presence of the largest statistically significant correlations with the level of adaptability of the unemployed in short-term vocational retraining; the possibility of influencing their level for a very limited period of psychological training; correction of levels of cognitive properties without loss of personal integrity and opportunities for self-development and self-improvement; the presence of a psychological factor chosen for the program as part of a combined factor influencing adaptability. Critical thinking, personal values "independence" and "independence in an activity", creative thinking are defined by the factors which can be used in the complex program on the increase of adaptability of unemployed at short-term professional retraining.
Постановка проблеми. Ймовірність або необхідність зміни професії внаслідок соціальної, технологічної, комунікативної динамічності сучасного світу з кожним роком зростають. Зміна професії чи об'єднання компетенцій кількох професій у новій конфігурації приводять до необхідності професійного перенавчання у дорослому віці, що в свою чергу потребує від особистості здатності адаптуватися до змін соціального середовища, до вимог нової сфери професійної діяльності. Дослідженням проблем адаптації, в тому числі такого її аспекту як адаптивність займались Ж. Піаже, Г. Селье, У. Найсер, Г. Балл, К. Роджерс, А. Началджанов, А. Петровський, А. Реан, Т. Шибутани, А. Жмиріков, А. Алексюк, О. Скри- пченко, І. Була, Л. Закутська, О. Мороз, О. Плотнікова, М. Левченко, І. Сабанадзе, В. Семиченко, Г. Хомич, I. Бойко, Н. Максимова, Г. Чуткіна та багато інших [1-4].

Вивчення адаптивності $€$ вагомим аспектом дослідження проблеми адаптації особистості як такої їі властивості, що дає змогу своєчасно ліквідовувати або компенсувати наслідки дій несприятливих факторів оточуючого середовища та визначає спроможність досягати стану адаптивності, зберігаючи при цьому ядро особистості при мінливості зовнішніх факторів [5]. В основі такої властивості особистості лежать особливості когнітивної, мотиваційно-потребнісної, емоційної сфер [6]. На рівень адаптивності впливають як зовнішні 
чинники (умови життєдіяльності, вплив виховання i освіти, соціальна підтримка), так і внутрішні чинники (індивідуальні психологічні особливості, особисті цінності, рівень інтелектуального розвитку, критичного, творчого мислення, рівні емоціональної експресії та комунікативних стосунків, вікові характеристики). І. Біла вказує, що адаптивні здібності являють собою інтегральну надбудову над іншими окремими здібностями, яка забезпечує досягненні цілей адаптації, успіх різних видів діяльності особистості [4]. А. Маклаков як головний компонент адаптаційних можливостей розглядає поняття особистісного адаптаційного потенціалу як характеристики рівнів розвитку пов'язаних між собою індивідуально-психологічних особливостей особистості, що є найбільш значущими для регуляції психічної діяльності та процесу адаптації. Ці рівні зумовлюють межу факторів зовнішнього середовища, до яких індивід здатен пристосуватись [7]. Згідно 3 точкою зору С. Ларіонової успішність соціально-психологічної адаптації «визначається адаптаційними ресурсами особистості і особливостями конкретного середовища, в умовах якого відбувається задоволення базової потреби особистості в позитивному ставленні, що видається можливим тільки в разі відповідності результатів діяльності особистості вимогам соціуму. Адаптаційні ресурси особистості - це шерег їі соціально-психологічних та індивідуальних характеристик, які визначають ступінь адаптованості особистості у конкретних соціальних умовах» [8]. Дослідниця виділяє такі адаптаційні властивості особистості: ціннісні орієнтації, «Я-концепцію», комунікативні властивості особистості, індивідуально-особистісні та емоційно-вольові особливості, адаптаційні властивості інтелекту. Останній компонент направляє, систематизує, корегує всю систему процесу адаптації, всі вищезазначені ii складові, тим самим окреслюючи вибір відповідних різновидів поведінки, визначення сфер та структури діяльності, рішень, висновків особистості при зміні соціальних умов [8]. Чимало сучасних досліджень адаптивності при зміні занять і життєвих ролей, які являють у своїй сукупності загальну спрямованість саморозвитку особистості, проведено зарубіжними вченими. Зазвичай у таких дослідженнях використовується термін «кар'єрна адаптивність» [9; 10]. Однією з відомих сучасних теорій адаптивності $€$ теорія конструювання кар'єри М. Савикаса. Вона описує конструкцію кар'єрної адаптивності, яка враховує чотири головних фактори: кар'єрний фокус, кар'єрний контроль, кар'єрний інтерес і кар'єрну впевненість в собі. Згідно поглядів М. Савіцкаса, кар'єрна адаптивність - це орієнтований на майбутнє психосоціальний ресурс, який необхідний особистості для планування поточної діяльності та напрям- ків розвитку своєї кар'єри $[11 ; 12]$. Ще однією теорією, пов'язаною з адаптивністю, є теорія соціальної когнітивної кар'єри (ТСКК), яку розробив на початку двадцять першого століття дослідник Р.В. Лент $(2005,2013)$. Теорія Лента розглядає такі когнітивні проекції особистості як самоефективність, планування результатів та особистих цілей. Ці конструкції спираються як на особисті ресурси і здібності (особистісні властивості, вік, стать), так і на контекстуальні фактори (сім'я, культура, гендерна-рольова соціалізація). За допомогою всіх цих факторів формується спрямованість розвитку кар'єри $[13 ; 14]$. Серед теорій адаптивності останнього десятиріччя увагу науковців привертає теорія диверсифікованого портфелю (ДФП), яку розробили дослідники С. Чандра та Ф.Т. Леонг (2016) [15]. Згідно їі положень диверсифікований портфель дій, ролей і досвіду призводить до більшої пристосовності особистості в житті. Дослідницька група, яку очолює Е.Дж. Мартін, розширила визначення адаптивності, що подається в теорії С. Чандра та Ф.Т. Леонг, включивши в неї не тільки спроможність до когнітивної і поведінкової регуляції, а ще й емоційну регуляцію як відповідь на мінливість і невизначеність соціального середовища. (Martin, Nejad, Colmar, \& Liem, 2013). Вчений назвав таке визначення «тристороннім» підходом до адаптивності [16]. Серед останніх досліджень науковці виділяють також метаналіз адаптивності, проведений С.В. Рудольфом (2017). Результати дослідження показали зв'язок кар'єрної адаптивності 3 особистісними структурами індивідуумів: позитивно кар'єрна адаптивність корелює 3 плануванням кар'єри, дослідженням кар'єри і самоефективністю під час ухвалення рішень про перспективи діяльності [17]. Масштабні дослідження адаптивних можливостей до військової кар'єри провели китайські дослідники Веньмо Чжан, Юаньюань Сюй, Лі Пен, Чень Бянь Йонджу Ю, Ін Лі, Мін Лі, результатом яких стала анкета адаптивних можливий до військової кар'єри (АМВК), що показала високу валідність і надійність (2020 р.). Анкета АМВК включає тестування по п'яти наступним факторам: здатність до організації і злиття, комунікативна здатність, здатність до навчання, здатність до регулювання емоцій, здатність до трансформації кар'єри. Китайські вчені рекомендують використовувати анкету АМВК як ефективний інструмент для вимірювання кар'єрної адаптивності військовослужбовців [18]. Отже, можливо зазначити, що дослідження адаптивності та їі факторів були в основному зосереджені в двох напрямках: перший - це дослідження контентних факторів, пов'язаних 3 навколишнім середовищем, другий - це дослідження індивідуальних особливостей адаптантів. Дослідження, пов'язані 3 вивченням впливу особливих властивостей на 
адаптивність у різних видах життєдіяльності, були найбільш актуальними в зарубіжному і вітчизняному науковому просторі останніх років. Однак дотепер досить нерозробленою лишається проблема щодо впливу когнітивних властивостей особистості безробітного на його адаптивність при короткостроковому професійному перенавчанні.

Мета статті полягає у виявленні взаємозв'язків між когнітивними чинниками адаптивності безробітних при короткостроковому професійному перенавчанні, визначенні когнітивних чинників, рівні яких змінюються при психологічному розвиваючому тренінгу.

Виклад основного матеріалу. Для досягнення мети використано результати власних емпіричних досліджень на базі Одеського центру професійно-технічної освіти державної служби занятості України. Досліджено 229 безробітних, які проходили короткострокове професійне перенавчання. Термін навчання в середньому складав близько чотирьох місяців. Під час проведення дослідження використано психодіагностичний інструментарій, який передбачає такі методики: багаторівневий особистісний опитувальник «Адаптивність» А.Г. Маклакова i C.В. Чермяніна, методику дослідження соціально-психологічної адаптації К. Роджерса - Р. Даймонд, методику Ш. Шварца «Вивчення цінностей особистості», тест творчого мислення Торенса (фігурна форма), тест на рівень інтелекту Кеттелера, тест критичного мислення Л. Старки [19]. Згідно 3 багаторівневим особистісним опитувальником «Адаптивність» А.Г. Маклакова і С.В. Чермяніна $51,0 \%$ досліджених мали невисокий особистий адаптивний потенціал, 34,9 \% - середній, 14,1 \% - високий. У цій методиці акцент дослідження адаптивної спроможності зміщений на соціально-психологічні характеристики та соціальний розвиток особистості (здатність регулювати стосунки з соціальним оточенням, соціальне схвалення, вміння побудувати відносини з іншими людьми, адекватне сприймання пропонованої соціальної ролі в суспільстві). Можна зазначити, що більше половини респондентів мають низький рівень показника «особистий адаптивний потенціал», що демонструє недостатньо розвинені здібності саме до аналізу соціального оточення, свого місці в ньому. Згідно 3 показником шкали «інтегральний показник адаптації» (СПА) методики К. Роджерса та Р. Даймонда 59,8 \% слухачів мали «високий рівень», 40,2 \% респондентів мали «середній рівень». Інтегральний показник адаптації відображає такі адаптивні властивості особистості як «адаптивність» $\mathrm{i}$ «дездаптивність», самоприйняття, прийняття інших, емоційний комфорт, інтернальність, прагнення домінування, ескапізм.

Кореляційний аналіз виявив позитивні зв'язки високого рівня $(\mathrm{p}<0,01)$ між особистим адаптивним потенціалом (методика А.Г. Маклакова i
С.В. Чермяніна) та рівнем інтелекту, рівнем критичного мислення, такими особистими цінностями як «самостійність» і «самостійність у поведінці», негативні - 3 особистими цінністю «традиції в поведінці» $(\mathrm{p}<0,01)$ та «конформізм в поведінці» $(\mathrm{p}<0,05)$. Позитивні кореляційні зв'язки високого рівня $(\mathrm{p}<0,01)$ було виявлено між інтегральним показником адаптації (методика СПА) та рівнями загального інтелекту, критичного мислення, «самостійності», «самостійності в поведінці» та «гедонізмом». Кореляційні зв'язки більш низького рівня $(\mathrm{p}<0,05)$ були виявлені між інтегральним показником адаптації та рівнем творчого мислення, такими особистими цінностями як влада, досягнення, універсалізм, універсалізм в поведінці, доброта в поведінці, негативні зв'язки (рівня $\mathrm{p}<0,05)$ - між інтегральним показником адаптації та такими особистими цінностями як влада в поведінці, конформізм в поведінці.

За результатами факторного аналізу за чинниками, які мають статистично значимі зв'язки 3 адаптивністю безробітних при професійному перенавчанні виділено п'ять факторів, які в сумі описують $66,89 \%$ аналізу вибірки всіх чинників та мають вплив на рівень адаптивності особистості безробітного при короткостроковому професійному перенавчанні, а саме:

1-й фактор містить такі змінні: рівень інтелекту, критичне мислення. Його названо «фактором інтелекту і критичного мислення». Змінна «критичне мислення» визначає послідовність розумових дій, спрямованих на перевірку систем висловлювань 3 метою з'ясування їх відповідності відомим фактам та ухваленні ретельно обміркованих та незалежних рішень [20]. Для особистості, яка володіє критичним мисленням, предметом дослідження $€$ вивчення якості свого мислення. Змінна «рівень інтелекту» розуміється як рівень загальних здібностей до пізнання, розуміння та розв'язання проблем, як продукт функціонування свідомості і мислення, в якому сполучаються всі пізнавальні здібності та створюється інформаційний потенціал знань особистості. Тобто інтелект визначає рівень тих здібностей, за допомогою яких здійснюється критичне мислення. Обидві змінні мають найвищу ступінь кореляційних зв'язків 3 адаптивністю $(\mathrm{p}<0,01)$.

2-й фактор сформували такі змінні: самостійність, самостійність у поведінці, гедонізм, досягнення. Цей фактор можна назвати «фактором самостійності та цілеспрямованості». Особисті цінності «самостійність», «самостійність в поведінці» інтерпретовано як незалежність особистого мислення та способу дій, творчість, бажання автономності. Змінна «гедонізм» має наступні мотиваційними цілі: задоволення від життя, чуттєві задоволення. Особиста цінність «досягнення» 
орієнтована на особистий успіх, відповідність соціальним стандартам, компетентність. Загальні риси 2-го фактора - задоволення від звершень, творчості, самостійного компетентного вирішення проблем. Найбільш вагомі кореляційні зв'язки 3 адаптивністю мають змінні «самостійність», «самостійність в поведінці» $(\mathrm{p}<0,01)$.

До 3-го фактора ввійшли такі змінні: традиції в поведінці, універсалізм, універсалізм в поведінці, конформізм, конформізм в поведінці, доброта в поведінці. Цей фактор можливо назвати «фактором традицій і добропорядності». Мотиваційними цілями чинника «традиції в поведінці» $\epsilon$ повага, прийняття норм, правил, звичаїв, культури суспільства, які проявляються в реальних діях особистості безробітного. Для змінних, що представляють особисті цінності «універсалізм», «універсалізм в поведінці» характерні розуміння інших, терпимість, захист благополуччя людей та природи. Змінні «конформізм», «конформізм у поведінці» мають мотиваційними цілями припинення дій та спонукань до дій, які можуть завдати шкоди іншим, і схвалення дій, що відповідають соціальним очікуванням. Для змінної, що становить особисту цінність «доброта в поведінці», притаманні турбота про благополуччя та здоров'я близьких, відповідальність, терпимість, дбайливість. Загальними рисами 3-го об'єднаного фактору є добровільна покора, терпимість, прийняття звичаїв і норм суспільства, відповідність соціальним очікуванням. Найбільші кореляційні зв'язки 3 адаптивністю в цій групі чинників має чинник «традиції в поведінці» $(\mathrm{p}<0,01)$.

До 4-го фактора ввійшли такі змінні: влада, влада в поведінці. Його визначено як «фактор влади». Особисті цінності «влада», «влада в поведінці» спрямовані на досягнення та збереження соціального статусу, домінування, досягнення авторитету у суспільній групі, багатства, суспільної поваги. Загальні риси змінних фактору повністю збігаються. Обидві змінні мають статистично значимі кореляційні зв'язки з інтегральним показником адаптації $(\mathrm{p}<0,05)$.

5-й фактор складає змінна «творче мислення». Це «фактор творчості». Творчою визначено діяльність, пов'язану зі створенням суб'єктивно і об'єктивно нових ідей, використанням нестандартних підходів для розв'язання проблем, пов'язану з відкритістю до будь-яких інновацій, здатністю відхилятися у мисленні від стереотипів і традиційних схем. «Творче мислення» статистично значимо пов'язано 3 інтегральним показником адаптації $(\mathrm{p}<0,05)$.

Визначимо критерії відбору з досліджуваних когнітивних чинників адаптивності таких, які можливо задіяти у вправах психологічного тренінгу комплексної програми по підвищенню адап- тивності безробітних під час короткострокового професійного перенавчання. Такими критеріями є:

- наявність найбільших статистично значимих кореляційних зав'язків з рівнем адаптивності безробітних при короткостроковому професійному перенавчанні;

- можливість впливу на їх рівень за досить обмежений час психологічного тренінгу;

- можливість корекції рівня когнітивної властивості без втрати при цьому особистісної цілісності та можливостей саморозвитку і самовдосконалення;

- присутність когнітивного чинника, що обирається для програми, у складі об'єднаного фактору впливу на адаптивність.

У короткостроковий психологічний розвиваючий тренінг віднесено когнітивні чинники: критичне мислення, особисті цінності «самостійність» та «самостійність в діяльності», творче мислення за наступними властивостями:

- ці чинники мали найбільш міцні кореляційні зв'язки з адаптивністю безробітних при короткостроковому професійному перенавчанні $(\mathrm{p}<0,01)$. Це когнітивні чинники: рівень інтелекту, критичне мислення, особиста цінність «самостійність», особиста цінність «самостійність в поведінці». Проте інтелект хоча і має високий рівень статистично значимих зав'язків 3 адаптивністю слухачів, але потребує часу навчання, щоб мати змогу впливати на його рівень позитивно, тому цей чинник не включено до корегування у психологічному тренінгу;

- здатність мислити критично, особисті цінності «самостійність в діяльності» та «самостійність» вдалося покращити за час проведення психологічного розвиваючого тренінгу, тим самим підвищивши адаптивність безробітних при короткостроковому професійному перенавчанні, що призводить до підвищення якості професійного навчання;

- творче мислення є відособленим фактором впливу на адаптивність слухачів, рівень якого можливо покращати за допомогою психологічного тренінгу без втрати особистісної цілісності, можливостей саморозвитку і самовдосконалення.

Висновки. За результатами дослідження впливу когнітивних чинників на рівень соціально-психологічної адаптивності безробітних при короткостроковому професійному перенавчанні та аналізу взаємозв'язків між цими когнітивними чинниками адаптивності було виявлено такі, що, маючи статистично значимі кореляційні зв'язки 3 адаптивністю, можуть бути покращені. Зазначимо, що проведення психологічного розвиваючого тренінгу відбувається 3 позитивним впливом на рівень адаптивності без втрати при цьому особистісної цілісності адаптанта. До чинників, що відповідають вищезазначеним критеріям від- 
несено: критичне мислення, особисті цінності «самостійність» та «самостійність в діяльності», творче мислення.

Перспективами подальших напрацювань дослідження вбачається: вдосконалення комплексної програми по підвищенню адаптивності безробітних при короткостроковому професійному перенавчанні, яка включає діагностичний інстру- ментарій для визначення рівня адаптивності на початку програми і по іiі закінченню та тренінг по корекції чинників адаптивності 3 метою підвищення ऑii рівня; проведення досліджень ефективності комплексної програми по підвищенню адаптивності безробітних при короткостроковому професійному перенавчанні 3 метою піi поліпшення та розширення.

\section{ЛІТЕРАТУРА}

1. Пиаже Ж. Психология интеллекта. СПб.: Питер, 2003. стр. 192.

2. Балл Г.А. Понятие адаптации и его значение для психологии личности. Bonpocы психологии. 1989. № 1. C. $92-100$.

3. Семиченко В.А. Проблема особистісного розвитку й саморозвитку в контексті неперервної професійної освіти. Педагогіка і психологія. 2010. № 2. С. 46-57.

4. Біла I.М. Формування адаптивних здібностей дітей в умовах сім'ї. Актуальні проблеми психологіï: Зб. наук. праџь Інституту психологї̈ імені Г.С. Костюка НАПН Украӥни, 2017, вип. 15. С. 17-29.

5. Гарбузов В.И. Воспитание ребёнка в семье: Советы психотерапевта Санкт-Петербург: КАРО, 2015. $296 \mathrm{c}$.

6. Ростовцева М.В., Машанов А.А. Естестеннонаучные, психологические и философские аспекты адаптации человека. Весник КрасГАУ, 2013, № 6. С. 184-190. URL: https://cyberleninka.ru/article/n/ estestvennonauchnye-psihologicheskie-i-filosofskie-aspekty-adaptatsii-cheloveka/viewer. (дата звернення 16.06.20)

7. Маклаков А.Г. Основы психологического обеспечения профессионального здоровья военнослужащих: Автореф. дис. ... д-ра психол. наук. СПб., 1996. 50 с.

8. Ларионова С.А. Концептуальная модель социально-психологической адаптации личности. Ежегодник Российского психологического общества: Материалы 3-го Всероссийского съезда психологов. СПб. 2003, т. 5. С. 39-42.

9. Гриншпун С.С. «Академия Х»: подготовка американцев к жизни и труду. Педагогика. 2004, № 4. C. $103-108$.

10. Super, D.E., \& Sverko, I. Life roles, values and careers. International findings of work importance study. 1995. P. 26-32.

11. Savickas, M.L. The theory and practice of career construction. Career Development and Counseling: Putting Theory and Research to Work; Lent, R.W., Brown, S.D., Eds.; John Wiley \& Sons: Hoboken, NJ, USA, 2005; pp. 42-70.

12. Savickas, M.L., Porfeli, E.J. Career Adapt-Abilities Scale: Construction, reliability, and measurement equivalence across 13 countries. Journal of Vocational Behavior. 2012, 80. P. 661-673.

13. Lent, R. W. Career-life preparedness: Revisiting career planning and adjustment in the new workplace. The CareerDevelopmentQuarterly,2013,61.P2-14.URL:http://dx.doi.org/10.1002/j.2161-0045.2013.00031.x (дата звернення 21.08.2020)

14. Lent, R.W., Miller, M.J., Smith, P.E., Watford, B.A., Lim, R.H., Hui, K., Morrison, M.A., Wilkins, G., $\&$ Williams, K. Social cognitive predictors of adjustment to engineering majors across gender and race/ ethnicity. Journal of Vocational Behavior. 2013, 83. P. 22-30.

15. Chandra, S., \& Leong, F. T. (2016). A diversified portfolio model of adaptability. American Psychologist. 2016, 71. P. 847-862. URL: https://doi.org/10.1037/a0040367 (дата звернення 16.10.20).

16. Martin, A.J., Yu, K., Ginns, P., \& Papworth, B. Young people's academic buoyancy and adaptability: Acrosscultural comparison of China with North America and the United Kingdom. Educational Psychology. 2016, 37. P. 930-946. URL: https://doi.org/10.1080/01443410.2016.1202904 (дата звернення 17.10.20)

17. Rudolph, C.W.; Lavigne, K.N.; Zacher, H. Career adaptability: A meta-analysis of relationships with measures of adaptivity, adapting, responses, and adaptation results. J. Vocat. Behav. 2017, 98. P. 17-34.

18. Wenmo Zhang, Yuanyuan Xu, Li Peng, Chen Bian, Yongju Yu, Ying Li and Min Li. Military Career Adaptability Questionnaire in China: Development and Validation. Front. Psychol. 2020, 10 March. URL: https://doi.org/10.3389/fpsyg.2020.00280 (дата звернення 17.10.20)

19. Хубетов О.В. Когнітивні властивості та особисті цінності як чинники адаптивності при короткочасному професійному навчанні. Проблеми сучасної психологї̈: науковий журнал. 2020, № 17. С. 59-68.

20. Брюшинкин В.Н. Критическое мышление и аргументация. / Калининград: Изд-во Калинингр. гос. ун-та, 2003. С. 29-34. 


\section{REFERENCES}

1. Piazhe Zh.(2003) Psikhologiya intellekta [Psychology of intelligence]. SPb.: Piter. P. 192 (in Russian).

2. Ball G. A.(1989) Ponyatie adaptatsii i ego znachenie dlya psikhologii lichnosti [The concept of adaptation and its significance for personality psychology]. Voprosy psikhologii, № 1, pp. 92-100 (in Russian).

3. Semychenko V.A. (2010) Problema osobystisnoho rozvytku y samorozvytku v konteksti neperervnoi profesiinoi osvity [The problem of special development and self-development in the context of continuous professional education]. Pedahohika i psykholohiia. № 2, pp. 46-57 (in Ukrainian).

4. Bila I.M. (2017) Formuvannia adaptyvnykh zdibnostei ditei v umovakh simi [Formation of adaptive abilities of children in the family environment ]. Aktualni problemy psykholohii [Zb. nauk. prats Instytutu psykholohii imeni H.S. Kostiuka NAPN Ukrainy], vol. 15, pp. 17-29 (in Ukrainian).

5. Garbuzov V. I. (2015) Vospitanie rebyonka v sem 'e: Sovety` psikhoterapevta [Raising a child in a family: Tips from a psychotherapist]. Sankt-Peterburg: KARO. P. 296 (in Russian).

6. Rostovceva M. V., Mashanov A. A. (2013) Estestennonauchnye, psihologicheskie i filosofskie aspekty adaptacii cheloveka [Natural science, psychological and philosophical aspects of human adaption] Vesnik KrasGAU [Bulletin of the Krasnoyarsk Agrarian Institute] (electronic journal), no 6, pp. 184-190. Retrieved from: https://cyberleninka.ru/article/n/estestvennonauchnye-psihologicheskie-i-filosofskie-aspekty-adaptatsii-cheloveka. (in Russian)

7. Maklakov A.G. (1996) Osnovy psikhologicheskogo obespecheniya professionalnogo zdorovya voennosluzhashchikh [The basics of psychological support for the professional health of military personnel] Extended abstract of the D.Sc. thesis in psychology. SPb. P. 50 (in Russian).

8. Larionova S.A. (2003) Kontseptualnaya model sotsialno-psikhologicheskoy adaptatsii lichnosti [Conceptual model of social and psychological adaptation of the personality]. Yearbook of the Russian Psychological Society: Materials of the 3rd All-Russian Congress of Psychologists. SPb, vol. 5, pp. 9-42 (in Russian).

9. Grinshpun S.S. (2004) «Akademiya Kh»: podgotovka amerikantsev k zhizni i trudu. [Academy X: Preparing Americans for Life and Work]. Pedagogika, no. 4, pp. 103-108 (in Russian).

10. Super, D. E., \& Sverko, I. (1995) Life roles, values and careers. International findings of work importance study. P. 26-32. (in English).

11. Savickas, M.L. (2005) The theory and practice of career construction. Career Development and Counseling: Putting Theory and Research to Work; Lent, R.W., Brown, S.D., Eds.; John Wiley \& Sons: Hoboken, NJ, USA, pp. 42-70 (in English).

12. Savickas, M.L., Porfeli, E.J. (2012) Career Adapt-Abilities Scale: Construction, reliability, and measurement equivalence across 13 countries. Journal of Vocational Behavior, no 80, pp. 661-673 (in English).

13. Lent, R. W. (2013) Career-life preparedness: Revisiting career planning and adjustment in the new workplace. The Career Development Quarterly, no 61, pp. 2-14. Retrieved from: http://dx.doi.org/10.1002/ j.2161-0045.2013.00031.x (in English).

14. Lent, R.W., Miller, M.J., Smith, P.E., Watford, B.A., Lim, R.H., Hui, K., Morrison, M.A., Wilkins, G., \& Williams, K. (2013) Social cognitive predictors of adjustment to engineering majors across gender and race/ethnicity. Journal of Vocational Behavior, no 83, pp. 22-30 (in English)

15. Chandra, S., \& Leong, F. T. (2016). A diversified portfolio model of adaptability. American Psychologist, no 71, pp. 847-862. Retrieved from: https://doi.org/10.1037/a0040367(in English)

16. Martin, A.J., Yu, K., Ginns, P., \& Papworth, B. ( 2016) Young people's academic buoyancy and adaptability: A cross-cultural comparison of China with North America and the United Kingdom. Educational Psychology? no 37, pp. 930-946. Retrieved from: https://doi.org/10.1080/01443410.2016.1202904 (in English)

17. Rudolph, C.W.; Lavigne, K.N.; Zacher, H. (2017) Career adaptability: A meta-analysis of relationships with measures of adaptivity, adapting, responses, and adaptation results. J. Vocat. Behav. no 98, pp. 17-34 (in English)

18. Wenmo Zhang, Yuanyuan Xu, Li Peng, Chen Bian, Yongju Yu, Ying Li and Min Li. (2020) Military Career Adaptability Questionnaire in China: Development and Validation. Front. Psychol., 10 March. Retrieved from: https://doi.org/10.3389/fpsyg.2020.00280 m (in English)

19. Khubetov O.V. ((2020) Kohnityvni vlastyvosti ta osobysti tsinnosti yak chynnyky adaptyvnosti pry korotkochasnomu profesiinomu navchanni [Cognitive properties and personal values as factors of adaptability in short-term professional training]. Problemy suchasnoi psykholohii: naukovyi zhurnal, № 17, pp. 59-68 (in Ukrainian).

20. Brushinkin V.N. (2003) Kriticheskoe myshlenie i argumentatsiya [Critical thinking and argumentation]. Kaliningrad: Izd-vo Kaliningr. gos. un-ta. P. 29-34 (in Russian). 